Article

\title{
The Concept of Sustainability in the Romanian Top Universities' Strategic Plans
}

\author{
Simona Șimon * (1), Claudia E. Stoian $(1)$ and Vasile Gherheș \\ Department of Communication and Foreign Languages, Politehnica University of Timișoara, \\ 300006 Timișoara, Romania; claudia.stoian@upt.ro (C.E.S.); vasile.gherhes@upt.ro (V.G.) \\ * Correspondence: simona.simon@upt.ro
}

Received: 28 February 2020; Accepted: 30 March 2020; Published: 1 April 2020

check for updates

\begin{abstract}
The concept of sustainability has been given more and more attention lately as the effects of climate change drastically impact society and threaten the wellbeing of future generations. In this context, universities are expected to build bridges between the academic and research communities on the one hand and society on the other, and to further the values associated with this concept in order to care for the generations to come. Thus, the present study describes the causes that have led to the emergence of this concept, defines it, and highlights some of the actions taken by universities and researchers. The question raised regards the position of the top Romanian universities towards the concept of sustainability. The way it is used explicitly in their strategic plans is viewed as proof as to whether the universities give it prominence or not, and as such, act accordingly. In order to achieve the primary objective of the research, a quantitative and a qualitative analysis were carried out. The main conclusion drawn is that the top Romanian universities are still at the beginning in terms of raising awareness about the concept and in terms of implementing sustainable measures in the domains that help them build sustainable universities.
\end{abstract}

Keywords: strategic plan; sustainability; sustainable development; durable development; university; appraisal theory

\section{Introduction}

From the very beginning of humankind onwards, humans have changed the environment in order first to survive and then to improve their standard of living. The first major change took place about 10,000 years ago, when plants and animals were domesticated, determining a better food production, which led to a better survival rate of the people and to the social and economic development of human communities. This agrarian revolution, as it is known in history, was followed by four industrial ones, which introduced mechanical production for the first time, thus contributing to the emergence of mass, computer- and cyber-physical system-based production [1-4]. All these revolutions have impacted the economic, social and cultural development of mankind, on the one hand, and the environment, on the other [1-5]. The most dramatic shift in human society occurred during the first industrial revolution, and the entire societal development has been built on it from then on. Although the changes were for the best, they happened at the expense of the environment, and, implicitly, of humanity, whose very existence has been threatened ever since. To prevent an environmental catastrophic end, people from all walks of life started to speak out, as early as the 19th century, about the main challenges posed by industrial development to human society [3-6]. Thus, a new branch of science, called ecology, appeared in the mid-19th century to deal with the environmental problems caused by a century of industrialization. However, ecologists became more and more active and visible outside their professional circles in the second half of the 20th century [6]. It was in the 20th century when people started to realize that attitudes and behaviors towards the environment must be altered in order to 
ensure the survival of future generations. The United Nations Educational, Scientific and Cultural Organization (UNESCO) has pointed out since 1968 that such a shift should take place across all the sectors of our society, involving private and public organizations, on the one hand, and national and international bodies, on the other $[7,8]$. In order to attain such a goal, the population needs to be environmentally educated on a global scale $[9,10]$. Thus, in 1977, in Georgia, at the UN International Conference on Environmental Education in Tbilisi, environmental (ecological) education was defined for the first time, and its importance for the generations to come was highlighted. Then, in 1992, in Rio de Janeiro, at the World Conference on Environment and Development, the focus was on education for sustainable development, a newly introduced concept. While environmental (ecological) education is usually taught in schools, in some subjects, and it tackles environmental problems and the way people should act in order to protect the environment, education for sustainable development approaches environmental problems in an integrated way, taking into account cultural, ethical, social and economic issues, building a set of values that should be promoted through education, be it formal, non-formal or informal. In other words, education for sustainable development deals with environmental (ecological) education in a much broader and more complex way.

\section{Sustainability at the University Level}

The concept of sustainable development was used for the first time in 1987, in the "Report of the World Commission on Environment and Development: Our Common Future", also known as the Brundtland Report, as follows:

"Humanity has the ability to make development sustainable to ensure that it meets the needs of the present without compromising the ability of future generations to meet their own needs. The concept of sustainable development does imply limits—not absolute limits but limitations imposed by the present state of technology and social organization on environmental resources and by the ability of the biosphere to absorb the effects of human activities. But technology and social organization can be both managed and improved to make way for a new era of economic growth. The Commission believes that widespread poverty is no longer inevitable. Poverty is not only an evil in itself, but sustainable development requires meeting the basic needs of all and extending to all the opportunity to fulfil their aspirations for a better life. A world in which poverty is endemic will always be prone to ecological and other catastrophes." [11]

In other words, sustainable development refers to the actions taken by humans in order to develop social communities that are viable from an economic and environmental point of view, and that are equitable for both present and future generations. As the main roles of universities are, on the one hand, to generate and disseminate knowledge [12] and, on the other, to create institutional citizens, i.e., citizens actively involved in the development of society as a result of the social education received at the university level [13], higher education institutions worldwide have started to pay attention to the sustainable development, also referred to as sustainability [14], of our society as a whole. Thus, rectors, presidents and other representatives of various universities across the globe have signed declarations, charters and partnerships in which they agreed on the actions to be taken within the universities they represented in order to promote a sustainable development [15]. For example, the Talloires Declaration (1990), the Halifax Declaration (1991), the Kyoto Declaration (1993), the Swansea Declaration (1993), the Co-operation Programme in Europe for Research on Nature and Industry through the Co-ordinated University Studies (COPERNICUS) Charter (1994), the Global Higher Education for Sustainability Partnership (GHESP) (2000), the Lüneburg Declaration (2001), the Declaration of Barcelona (2004), the Graz Declaration (2005), the Turin Declaration (2009) and the Abuja Declaration (2009) highlight the moral obligation of universities to support the development of sustainable practices in contemporary society, and to propose a set of actions that could contribute to the achievement of such a goal. Thus, education for sustainable development should be included in curricula and approached transdisciplinarily. Everyone, including educators, should have lifelong access to updated knowledge and information on sustainability. Universities should cooperate with 
stakeholders (governmental and non-governmental, public and private organizations, students, parents and the public at large) to find sustainable solutions through research and implement them in campuses. All higher education institutions should create an institutional framework within which the university can operate so that sustainable practices can be developed $[10,12,15]$.

In order to build a sustainable university, four criteria must be met, namely, policy, operations, evaluation and optimization [10]. Policy refers to a set of values that define a university and that are the foundation for its development in general and its sustainable development in particular. The documents that reflect the university's policy are the university's strategy, its organizational structure and the university's statement, which includes its mission, vision and goals [10]. All of these as well as the public relations materials used by the university should explicitly make reference to sustainable development [14]. Operations comprise all the activities that take place daily in a university [10]. It is widely recognized that a university must perform in seven domains: (I) quality teaching, (II) research culture, (III) technological capacity building, (IV) accessibility to university education, (V) community engagement, (VI) internationalization and (VII) natural environment [12]. In these seven domains, sustainable measures should be first described in the university's policy documents and then implemented [12]. Evaluation presupposes that there are standards that need to be met and that their implementation within the university needs to be checked in order to assess the environmental, economic and societal indicators that define sustainable development. Finally, optimization aims at finding innovative solutions to the problems identified during the evaluation [10]. Various actions may be taken in order to meet these criteria, and some of them are presented at the beginning of the next section, in the literature review.

\section{Justification of the Present Study}

Building a sustainable university has become a central issue for many higher education institutions across the world. Therefore, many scholars discuss this matter in the research they conduct and disseminate their results in the scientific circles they frequent. Most of the literature dealing with this topic presents:

- the role of universities in promoting sustainable development [14,16-18],

- the declarations, charters and partnerships for sustainable development signed by university representatives [15],

- the managerial models needed in order to build sustainable universities [10,12,14,17,19-22],

- the actions taken at the university level to promote sustainable development, such as policy [14, 20,21,23], curricular design [20,23-28], sustainability programs for educators $[29,30]$ and sustainable practice $[20,21,31,32]$,

- the sustainability reports published by universities [21,33], and

- the university's engagement in the community [34-38].

The present study approaches the topic from a different perspective, namely, it aims at identifying the university's position towards its sustainable development by analyzing the strategic plan as an instance of public discourse that reflects the addresser's beliefs, values and ideologies at a certain moment. The concept of sustainability may be referred to implicitly, when sustainable measures are described without mentioning the concept, or explicitly, when the addresser resorts to explicit linguistic means, such as sustainability, sustainable development (durable development) and sustainable. It is the latter case that is examined in the present study because one of the premises on which building a sustainable university is based is that the concept is acquired and explicitly used in the university's policy documents, as already emphasized above.

Taking all this into account, the question raised by the present study is: What is the position taken by the top Romanian universities towards sustainable development and stated in their strategic plans? In order to answer this research question, two working hypotheses have been formulated: 
Hypothesis 1. The concept of sustainability is used frequently in all the strategic plans analyzed.

Hypothesis 2. The concept of sustainability appears in the universities' strategic plans in relation to the domains in which sustainable universities must perform.

The primary objective of the research is, thus, to highlight the stance taken by the top Romanian universities towards their sustainable development. To achieve it, the following secondary objectives have been set:

- identification of the words sustainability and sustainable, and of the phrase sustainable development (durable development) in the universities' strategic plans for 2016-2020,

- quantification of their frequency, and

- analysis of their linguistic context.

The first two secondary objectives support the first hypothesis (H1), while the last one supports the second hypothesis $(\mathrm{H} 2)$.

\section{Materials and Methods}

\subsection{Corpus of Analysis}

In 2011, the Law of National Education established that each Romanian university is placed in one of the following categories:

- advanced research- and teaching-oriented universities,

- teaching- and scientific research-oriented universities, and teaching- and artistic creation-oriented universities, and

- teaching-oriented universities.

The first class listed is the most prestigious one, and the last class the least prestigious one [39]. As leading universities are usually promoters of the cutting-edge trends in our society, and as sustainability is one of the top concerns of the 21st century, it is expected that the universities included in the first category raise awareness by explicitly talking about their sustainable development.

Following the assessment made by the Romanian Ministry of Education in 2011 [40], twelve universities, enumerated alphabetically, were classified as advanced research- and teaching-oriented universities, namely, Alexandru Ioan Cuza University of Iaşi, Babeș-Bolyai University, Bucharest University of Economic Studies, "Carol Davila" University of Medicine and Pharmacy Bucharest, "Gheorghe Asachi" Technical University of Iași, "Iuliu Haţieganu" University of Medicine and Pharmacy Cluj-Napoca, Politehnica University of Bucharest, Politehnica University Timişoara, Technical University of Cluj-Napoca, University of Agricultural Sciences and Veterinary Medicine Cluj-Napoca, University of Bucharest and University of Medicine and Pharmacy "Grigore T. Popa" Iași. The universities' names in English were taken from the English versions of their websites, thus observing the institutions' choice of how they officially refer to themselves.

In order to build the corpus, the universities' websites were searched for their 2016-2020 strategic plans. The reason lying behind the choice of the 2016-2020 interval is the fact that this is the one for which the most recent academic leadership elections were held. The only exception is Bucharest University of Economic Studies, whose strategic plan covers the period 2014-2020, that is one and a half rector's mandates, probably because the institution has considered continuity in action to be a necessity.

\subsection{Method of Analysis}

The method of analysis used to attain the present research objective comprises several steps. First, the words sustainability and sustainable, and the phrase sustainable development (durable development) 
were identified in the strategic plans of the twelve top universities in Romania. Second, a quantitative analysis was carried out to highlight the frequency with which they were used. The relevance of such a method of analysis has been emphasized by Sinclair [41] (p. 30), who considers that in order to study a text, one "need[s] to know how often each different word form occurs in it", and by Tribble and Jones [42], who propose frequency-sorted word lists as the most effective starting point for understanding a text. The present study looks at the frequency of the words and phrases in question, since it "can provide interesting information about the words that appear (and do not appear) in a text" [43] (p. 41). Word frequency is "a very simple property [of a word] laying, so to say, on the surface of the text" [44] (p. 1), and the result of its counting "can be used in typography, stenography, psychology, psychiatry, language teaching, cryptography, software production, etc." [44] (p. 1). Lately, even more scientific importance has been given to word frequency studies [44-46].

Finally, a qualitative analysis was conducted in order to identify the context in which the word or phrase appeared. For this, two aspects were taken into consideration: on the one hand, the meaning of the words sustainability and sustainable, and of the phrase sustainable development (durable development) interpreted from the point of view of Appraisal Theory, and on the other, the domain with which they were associated. Since in Romanian sustainable development and durable development are synonyms and used interchangeably, they were both considered.

Appraisal Theory investigates "the linguistic resources by which texts/speakers come to express, negotiate and naturalise particular inter-subjective and ultimately ideological positions" [47] (n.p.). Specifically, it focuses on "the language of evaluation, attitude and emotion, and with a set of resources which explicitly position a text's proposals and propositions interpersonally" [47] (n.p.). These linguistic resources are grouped in three main domains, i.e., Attitude, Engagement and Graduation.

Attitude is related to the evaluation of people, things and places, thus focusing on adjectives. It refers to the meanings by which the authors of texts link values or evaluations to people and happenings by recurring to emotional responses or to culturally established systems [47]. It includes three types: Affect, which expresses feelings; Judgement, which evaluates behavior or character on social grounds; and Appreciation, which evaluates objects, products and processes based on their composition, social value and impact $[47,48]$. These types seem to "accumulate significance on the basis of the company they keep and the relations they contract with other wordings in the text" [49] (p. 299).

As for Engagement, this adapts writers' commitment to what they evaluate. It focuses on the way in which the expression of judgements and attitudes manages and considers "the ever-present possibility of challenge or contradiction from those who hold differing views" [47] (n.p.). Thus, the textual voice may choose to engage with dialogic alternatives and negotiate meaning by disclaiming, proclaiming, entertaining and/or attributing. It may also adopt a monoglossic position, ignore possible alternatives and just present information $[47,48,50]$.

Lastly, Graduation adjusts the expressed feelings and opinions using Force and/or Focus. By means of Force, the textual voice may raise or lower the interpersonal impact, force or volume of what it is said. By Focus, in turn, Attitudes are either sharpened or softened [47].

Within this framework, the present study looks at instances of Appraisal resources. Among all its types, the only suitable one is Appreciation, as this focuses on inanimate things, such as "natural objects, manufactured objects, texts as well as more abstract constructs such as plans and policies" [47] (n.p.), encompassing "values which fall under the general heading of aesthetics, as well as a non-aesthetic category of 'social valuation'" [47] (n.p.). As such, strategic plans are official projects of the university, designed and written at a certain moment in time by somebody in particular, being, thus, the reflection of a certain society and culture. Moreover, the concept of sustainability is related to social values and has an impact on society due to the present culture that aims to protect the environment. Considering this, this study looks at the words sustainability and sustainable, and the phrase sustainable development (durable development). Although sustainability is not an adjective, the analysis was also applied to it, being a synonym of sustainable development (durable development). Their occurrence was interpreted 
in relation to their linguistic context of appearance, the entire text, the university's discourse and its current situation.

Because universities enable the transfer of knowledge from scientific circles to society, it is important for a university to excel in one of the following domains: (I) quality teaching, (II) research culture, (III) technological capacity building, (IV) accessibility to university education, (V) community engagement, (VI) internationalization and (VII) natural environment [12], as aforementioned. It is in these domains in which sustainable measures should be implemented in order to build a sustainable university, a university of the future that cares for our environment in order to ensure the existence of the generations to come. The explicit use of the words or phrase describing the concept of sustainability in association with one of the seven domains points to the university's preoccupation with developing sustainable practices.

The instances mirroring the use of sustainability, sustainable, and sustainable development (durable development) in their linguistic context in the strategic plans are given in a separate table for each university. These have been translated into English, appearing in their Romanian original form in the Appendix A. The instances have been numbered according to their order of appearance in the text, following the number assigned to each university, namely, Alexandru Ioan Cuza University of Iaşi (I), Babeș-Bolyai University (II), Bucharest University of Economic Studies (III), "Carol Davila" University of Medicine and Pharmacy Bucharest (IV), "Gheorghe Asachi” Technical University of Iași (V), "Iuliu Haţieganu" University of Medicine and Pharmacy Cluj-Napoca (VI), Politehnica University of Bucharest (VII), Politehnica University Timişoara (VIII), Technical University of Cluj-Napoca (IX), University of Agricultural Sciences and Veterinary Medicine Cluj-Napoca (X), University of Bucharest (XI) and University of Medicine and Pharmacy "Grigore T. Popa" Iași (XII).

\section{Results}

\subsection{Quantitative Analysis}

The results of the quantitative analysis, which shows the frequency of occurrence of the words sustainability and sustainable and of the phrases sustainable development and durable development in the selected corpus, are presented in Table 1.

Table 1. Frequency summary.

\begin{tabular}{|c|c|c|c|c|c|}
\hline Frequency & Sustainability & Sustainable & $\begin{array}{c}\text { Sustainable } \\
\text { Development }\end{array}$ & $\begin{array}{c}\text { Durable } \\
\text { Development }\end{array}$ & Total \\
\hline Alexandru Ioan Cuza University of Iaşi & 4 & 2 & - & - & 6 \\
\hline Babeș-Bolyai University & 1 & - & - & - & 1 \\
\hline Bucharest University of Economic Studies & - & 2 & - & - & 2 \\
\hline $\begin{array}{c}\text { "Carol Davila" University of Medicine and } \\
\text { Pharmacy Bucharest }\end{array}$ & - & 2 & - & 1 & 3 \\
\hline "Gheorghe Asachi" Technical University of Iași & 1 & - & - & 1 & 2 \\
\hline $\begin{array}{l}\text { "Iuliu Haţieganu" University of Medicine and } \\
\text { Pharmacy Cluj-Napoca }\end{array}$ & - & - & - & - & 0 \\
\hline Politehnica University of Bucharest & 2 & 1 & 1 & 2 & 6 \\
\hline Politehnica University Timişoara & 1 & 1 & 1 & 6 & 9 \\
\hline Technical University of Cluj-Napoca & 1 & - & - & 2 & 3 \\
\hline $\begin{array}{l}\text { University of Agricultural Sciences and } \\
\text { Veterinary Medicine Cluj-Napoca }\end{array}$ & - & 2 & - & - & 2 \\
\hline University of Bucharest & 3 & - & - & 1 & 4 \\
\hline $\begin{array}{l}\text { University of Medicine and Pharmacy "Grigore } \\
\text { T. Popa" Iași }\end{array}$ & 1 & 1 & 2 & 1 & 5 \\
\hline TOTAL & 14 & 11 & 4 & 14 & 43 \\
\hline
\end{tabular}

As can be seen in Table 1, not all the universities looked at use the word sustainability and/or its related forms in their strategic plans. In the document belonging to "Iuliu Haţieganu" University of Medicine and Pharmacy Cluj-Napoca [51], which is seven pages long, there is no instance of the words and phrases searched for. Another case is met in Babeș-Bolyai University's strategic plan, where sustainability appears only once. At the other end, there is Politehnica University Timişoara, 
which gives a lot of importance to sustainability, as indicated by the high number of occurrences. The other universities are along the continuum of the two extremes; Bucharest University of Economic Studies, "Gheorghe Asachi" Technical University of Iași and the University of Agricultural Sciences and Veterinary Medicine Cluj-Napoca have a small number of instances; Alexandru Ioan Cuza University of Iaşi, Politehnica University of Bucharest, and the University of Medicine and Pharmacy "Grigore T. Popa" Iași have a large number; while "Carol Davila" University of Medicine and Pharmacy Bucharest, the Technical University of Cluj-Napoca and the University of Bucharest are in between.

Regarding the words used, it appears that there is a certain preference, on the one hand, for the word sustainability, especially in the case of Alexandru Ioan Cuza University of Iassi and the University of Bucharest, and on the other hand, for the phrase durable development, being preponderantly used by Politehnica University Timişoara. There are, however, few universities that do not use the word sustainability at all, such as Bucharest University of Economic Studies, "Carol Davila" University of Medicine and Pharmacy Bucharest and the University of Agricultural Sciences and Veterinary Medicine Cluj-Napoca. The phrase durable development is not mentioned at all by Alexandru Ioan Cuza University of Iaşi, Babeș-Bolyai University, Bucharest University of Economic Studies and the University of Agricultural Sciences and Veterinary Medicine Cluj-Napoca. The next most used word is sustainable, which appears once or twice in the strategic plans of all the universities considered, except for Babeș-Bolyai University, "Gheorghe Asachi” Technical University of Iași, the Technical University of Cluj-Napoca and the University of Bucharest, where it is not present at all. Finally, the least used is the phrase sustainable development, which has a small number of occurrences and appears only once in the strategic plans of Politehnica University of Bucharest and Politehnica University Timişoara, and twice in that of the University of Medicine and Pharmacy "Grigore T. Popa" Iași.

\subsection{Qualitative Analysis}

The words sustainability and sustainable and the phrases sustainable development and durable development in the selected corpus are considered, on the one hand, from the viewpoint of Appreciation within the Appraisal framework, and on the other, of the domain with which they are associated. The Tables 2-12 present the instances analyzed in each of the strategic plans of the universities that build the corpus.

Table 2. The strategic plan of Alexandru Ioan Cuza University of Iaşi [52].

\begin{tabular}{|c|c|}
\hline Word/Phrase & Instance \\
\hline sustainability (I1) & $\begin{array}{l}\text { Establish an effective institutional dialogue with the managing authorities and the } \\
\text { implementing bodies, both in the consultation and pre-contracting phase and in the } \\
\text { implementation and sustainability phase (p. 5) }\end{array}$ \\
\hline sustainability (I2) & $\begin{array}{l}\text { The administrative component acts as a support element for the fulfilment of the functions } \\
\text { of education and research, being also one of the basic components for the sustainability of } \\
\text { the activity (p. 7) }\end{array}$ \\
\hline sustainable (I3) & $\begin{array}{l}\text { The specific objective is to ensure a sustainable management, through the optimal } \\
\text { functioning of the institution and the development of new investments (p. 7) }\end{array}$ \\
\hline sustainable (I4) & $\begin{array}{l}\text { The development of this type of activity can be sustainable and does not bring additional } \\
\text { costs, being able to materialize in a source of income for the University (p. 10) }\end{array}$ \\
\hline sustainability (I5) & $\begin{array}{c}\text { The valorization of research results in the socio-economic environment contributing } \\
\text { decisively to the sustainability of the activity, as well as to the guarantee of the necessary } \\
\text { financing (p. 15) }\end{array}$ \\
\hline sustainability (I6) & $\begin{array}{l}\text { ensuring the sustainability of the quality of the educational and research process-I } \\
\text { propose a process of selecting in the academic body, as tenured or associate teaching staff, } \\
\text { specialists with national or international recognition as well as promoting the best } \\
\text { graduates of the university and doctoral students in teaching and scientific research } \\
\text { activities (p. 19) }\end{array}$ \\
\hline
\end{tabular}


Table 3. The strategic plan of Babeș-Bolyai University [53].

\begin{tabular}{cc}
\hline Word/Phrase & Instance \\
\hline sustainability (II1) & Increasing UBB * incomes and ensuring the financial sustainability of all structures within \\
the university (p. 31)
\end{tabular}

${ }^{*}$ UBB is the Romanian acronym for Universitatea Babeș-Bolyai [Babeș-Bolyai University].

Table 4. The strategic plan of Bucharest University of Economic Studies [54].

\begin{tabular}{cc}
\hline Word/Phrase & Instance \\
\hline sustainable (III1) & Achieving new viable and sustainable partnerships with foreign universities and \\
European institutions (p. 18)
\end{tabular}

Table 5. The strategic plan of "Carol Davila" University of Medicine and Pharmacy Bucharest [55].

\begin{tabular}{cc}
\hline Word/Phrase & Instance \\
\hline sustainable (IV1) & $\begin{array}{c}\text { Sustainable contribution of the university to durable development and to the achievement } \\
\text { of the highest standard of health in Romania, in the EU and in the world (p. 11) }\end{array}$ \\
\hline $\begin{array}{c}\text { durable } \\
\text { development (IV2) }\end{array}$ & $\begin{array}{r}\text { Sustainable contribution of the university to durable development and to the achievement } \\
\text { of the highest standard of health in Romania, in the EU and in the world (p. 11) }\end{array}$ \\
\hline sustainable (IV3) & $\begin{array}{c}\text { Identification of feasible and sustainable alternatives for the transition from the current } \\
\text { state to the desirable one (p. 16) }\end{array}$ \\
\hline
\end{tabular}

Table 6. The strategic plan of "Gheorghe Asachi" Technical University of Iași [56].

\begin{tabular}{cc}
\hline Word/Phrase & Instance \\
\hline sustainability (V1) & $\begin{array}{c}\text { Developing a financial discipline of the institution, by clearly highlighting the incoming } \\
\text { and outgoing flows in university cost centers, in order to maintain its financial } \\
\text { sustainability (p. 9) }\end{array}$ \\
\hline $\begin{array}{c}\text { to carry out the activities of scientific research, development, innovation and technological } \\
\text { transfer, to valorize and disseminate their results, with the role of components that are } \\
\text { inseparable from the instructional-formative process, in order to contribute to } \\
\text { development (V2) }\end{array}$ & $\begin{array}{c}\text { technological, economic and socio-cultural progress, in the sense of durable development } \\
\text { and evolution towards the society of knowledge (p. 17) }\end{array}$ \\
\hline
\end{tabular}

Table 7. The strategic plan of Politehnica University of Bucharest [57].

\begin{tabular}{|c|c|}
\hline Word/Phrase & Instance \\
\hline $\begin{array}{c}\text { sustainable } \\
\text { development (VII1) }\end{array}$ & $\begin{array}{l}\text { We have perpetually tried to find solutions for the technological, economic, social and } \\
\text { sustainable development-related challenges of the environment in which we operate (p. 4) }\end{array}$ \\
\hline sustainable (VII2) & New possibilities for sustainable integration of biodiesel production (p. 13) \\
\hline $\begin{array}{c}\text { durable } \\
\text { development (VII3) }\end{array}$ & $\begin{array}{l}\text { There is also the thesis that the social responsibility of universities "contributes to durable } \\
\text { development, including the health and wellbeing of society, recognizes the expectations of } \\
\text { stakeholders, respects the international law and rules of conduct and complies with the } \\
\text { relevant rules of transparency and public accountability"(Martin, 2013) (p. 16) }\end{array}$ \\
\hline sustainability (VII4) & $\begin{array}{l}\text { Furthering the values of justice, ethics, academic freedom, tolerance, participatory } \\
\text { democracy, equal opportunities and sustainability (p. 19) }\end{array}$ \\
\hline $\begin{array}{c}\text { durable } \\
\text { development (VII5) }\end{array}$ & $\begin{array}{l}\text { A future concern is the greater involvement of students in research activities and projects, } \\
\text { wishing to stimulate them, in order to discover and create knowledge, to contribute to the } \\
\text { achievement of innovations and technological adaptations in specific fields, in the context } \\
\text { of durable development (p. 40) }\end{array}$ \\
\hline sustainability (VII6) & $\begin{array}{l}\text { Based on these realities, the economic-financial management will have to continue to } \\
\text { consider ensuring the financial sustainability of the university in all the components of its } \\
\text { functioning, in the medium and long term (p. 53) }\end{array}$ \\
\hline
\end{tabular}


Table 8. The strategic plan of Politehnica University Timişoara [58].

\begin{tabular}{|c|c|}
\hline Word/Phrase & Instance \\
\hline $\begin{array}{c}\text { durable } \\
\text { development (VIII1) }\end{array}$ & Axis V: Infrastructure and durable development (p. 10) \\
\hline $\begin{array}{c}\text { durable } \\
\text { development (VIII2) }\end{array}$ & $\begin{array}{l}\text { At the same time, they also include the directions on which the carrying out of the } \\
\text { activities related to the mission, namely the financial dimension and human resources, } \\
\text { depends, which are in turn dependent on infrastructure and the policies regarding durable } \\
\text { development, computerization (p. 11) }\end{array}$ \\
\hline sustainable (VIII3) & $\begin{array}{l}\text { Initiatives in this field aim to implement a sustainable strategy in the long term to increase } \\
\text { the performance of human capital (p. 18) }\end{array}$ \\
\hline $\begin{array}{c}\text { durable } \\
\text { development (VIII4) }\end{array}$ & $\begin{array}{l}\text { Objectives and support activities regarding infrastructure and durable development } \\
\text { (p. 19) }\end{array}$ \\
\hline $\begin{array}{l}\text { sustainability } \\
\text { (VIII5) }\end{array}$ & $\begin{array}{l}\text { Furthering of the concept of sustainability at the university campus level and at the level } \\
\text { of the other objectives of UPT * through measures that take into account (p. 20) }\end{array}$ \\
\hline $\begin{array}{c}\text { sustainable } \\
\text { development (VIII6) }\end{array}$ & $\begin{array}{l}\text { continuation and intensification of partnerships with the local administration in the } \\
\text { promotion of projects of public interest and sustainable development (p. 21) }\end{array}$ \\
\hline $\begin{array}{c}\text { durable } \\
\text { development (VIII7) }\end{array}$ & $\begin{array}{l}\text { Promotion of cluster-type regional structures, mainly in the field of durable development } \\
\text { (p. 32) }\end{array}$ \\
\hline $\begin{array}{c}\text { durable } \\
\text { development (VIII8) }\end{array}$ & $\begin{array}{l}\text { The development of a management strategy in the following years, so that by the year } 2025 \\
\text { (considered a crucial year by the deciders in the field of education), UPT presents an } \\
\text { efficient leadership, based on the flexible combination between a professional management } \\
\text { specific to an economic operator in an aggressive competitive system (which is able to } \\
\text { evaluate the present situation and to elaborate strategies and action plans that can be } \\
\text { implemented and monitored to ensure durable institutional development) (p. 34) }\end{array}$ \\
\hline $\begin{array}{c}\text { durable } \\
\text { development (VIII9) }\end{array}$ & $\begin{array}{l}\text { The increase in public and social responsibility by intensifying the active dialogue with the } \\
\text { extra-university environment, by involving the members of the university community in } \\
\text { the elaboration and implementation of public, social policies (e.g., for the protection of the } \\
\text { environment, opportunities and equal access, durable development), and to effectively } \\
\text { communicate its results in this domain (p. 35) }\end{array}$ \\
\hline
\end{tabular}

* UPT is the Romanian acronym for Universitatea Politehnica Timişoara [Politehnica University Timişoara].

Table 9. The strategic plan of the Technical University of Cluj-Napoca [59].

\begin{tabular}{cc}
\hline Word/Phrase & Instance \\
\hline $\begin{array}{c}\text { Wurable } \\
\text { development (IX1) } \\
\text { in the country, is facing both major challenges and real opportunities for durable } \\
\text { development, assuming both a pragmatic and a realistic approach focused on the real } \\
\text { needs of the regional and national socio-economic environment, by rethinking and } \\
\text { orienting the entire educational process, scientific research and innovation towards this } \\
\text { requirement (p. 3) }\end{array}$ \\
\hline sustainability (IX2) & $\begin{array}{c}\text { chronic underfunding of higher education and research in Romania, generating difficulties } \\
\text { in ensuring financial sustainability in terms of the quality of the academic act (p. 10) }\end{array}$ \\
\hline $\begin{array}{c}\text { durable } \\
\text { development (IX3) }\end{array}$ & Supporting durable urban development (p. 27) \\
\hline
\end{tabular}

Table 10. The strategic plan of the University of Agricultural Sciences and Veterinary Medicine Cluj-Napoca [60].

\begin{tabular}{cr}
\hline Word/Phrase & Instance \\
\hline sustainable $(\mathrm{X} 1)$ & $\begin{array}{r}\text { Incentivizing personal or collective initiatives that can attract the financial resources } \\
\text { needed for institutional development, including adequate additional salary remuneration; } \\
\text { support for priority projects that are sustainable (pp. 1-2) }\end{array}$ \\
\hline sustainable $(\mathrm{X} 2)$ & $\begin{array}{r}\text { While fee-based education in foreign languages is perfectly financially sustainable, the } \\
\text { fees applied to many programs in Romanian require a reassessment (p. 7) }\end{array}$ \\
\hline
\end{tabular}


Table 11. The strategic plan of the University of Bucharest [61].

\begin{tabular}{cc}
\hline Word/Phrase & Instance \\
\hline $\begin{array}{c}\text { durable } \\
\text { development (XI) }\end{array}$ & $\begin{array}{c}\text { Scientific research and academic training from the perspective of the principles of durable } \\
\text { development and sustainability (p. 2) }\end{array}$ \\
\hline sustainability (XI2) & $\begin{array}{c}\text { Scientific research and academic training from the perspective of the principles of durable } \\
\text { development and sustainability (p. 2) }\end{array}$ \\
\hline sustainability (XI3) & $\begin{array}{c}\text { Ensuring the institutional sustainability of the University of Bucharest by: Reducing } \\
\text { deficits, Strengthening the institutional culture, Developing investments (p. 3) }\end{array}$ \\
\hline sustainability (XI4) & $\begin{array}{r}\text { The recognition of the role of education as a long-term strategic investment, crucial for the } \\
\text { sustainability of Romania's development (p. 4) }\end{array}$ \\
\hline
\end{tabular}

Table 12. The strategic plan of the University of Medicine and Pharmacy “Grigore T. Popa" Iași [62].

\begin{tabular}{cc}
\hline Word/Phrase & Instance \\
\hline $\begin{array}{c}\text { sustainable } \\
\text { development (XII1) }\end{array}$ & Lack of a coherent sustainable development strategy (p. 57) \\
\hline sustainability (XII2) & $\begin{array}{c}\text { For the realization of the investment portfolio, the budget for income and expenses was } \\
\text { estimated in order to analyze the sustainability and feasibility of the proposals (p. 75) }\end{array}$ \\
\hline $\begin{array}{c}\text { durable } \\
\text { development (XII3) }\end{array}$ & $\begin{array}{c}\text { All these fields are important for the durable and sustainable development of UMF-Iași } \\
\text { and are found in the implementation plan for the operationalization of the strategic } \\
\text { objectives (p. 79) }\end{array}$ \\
\hline $\begin{array}{c}\text { sustainable } \\
\text { development (XII4) }\end{array}$ & $\begin{array}{c}\text { All these fields are important for the durable and sustainable development of UMF-Iași } \\
\text { and are found in the implementation plan for the operationalization of the strategic } \\
\text { objectives (p. 79) }\end{array}$ \\
\hline $\begin{array}{c}\text { sustainable (XII5) } \\
\text { financially sustainable, addressing new opportunities as they arise, remaining firm and } \\
\text { consistent in its essential directions (p. 79) }\end{array}$ \\
\hline
\end{tabular}

\subsubsection{Alexandru Ioan Cuza University of Iaşi}

The strategic plan of Alexandru Ioan Cuza University of Iaşi has 20 pages. The first time the word sustainability appears is related to other sources of financing. Within a financial frame, it is included in a series of action directions and specific measures to be followed and adopted by the university. Here, sustainability is considered to be a phase involving the obtainment of new sources of financing, after the implementation phase. Within the same frame, sustainability is discussed in relation to the university's administrative capacity and management, as an objective and a quality that the university should have. The document moves to the next topic, education, and sustainability goes along with it. In this topic, the development of the activity of completing the educational offer with a vocational one is presented as possibly sustainable. Once again, sustainability is associated with an activity, but the activity this time is research. One of the university's objectives, in the research field, is to develop facilities that support technological transfer, whose valorization ensures sustainability for the present activity and financing for future ones. The last time sustainability is mentioned is on page 19, in the part dedicated to human resources. The continuous training and development of human resources is an important objective for the university. In order to ensure this, three main action directions are considered, among which is ensuring the sustainability of the quality of educational and research processes. In this last instance, the rector intervenes directly by using the first person singular and proposing some measures. Taking the entire document into consideration, the domains referred to by the six instances identified in it are: quality teaching (I2, I4, I6), research culture (I2, I5, I6), and community engagement (I5). The concept of sustainability is used twice with no reference to any of the seven domains in which a university must perform (I1, I3).

Taking into account the length of the plan and the frequency of the concept focused on, sustainability is used quite often in the strategic plan of Alexandru Ioan Cuza University of Iaşi. It is mentioned throughout the entire document, being related to financing, management, administration, education, 
research, technological transfer and human resources. This indicates that the concept is an important one for the university.

\subsubsection{Babeș-Bolyai University}

Babes-Bolyai University presents its strategic plan for 2016-2020 throughout 35 pages. Within its strategy, the concept of sustainability appears only once towards the end of the document, being related to financial aspects. Among the university's objectives, increasing incomes in order to ensure the financial sustainability of the university's structures is mentioned. The use of the word sustainability refers to none of the seven domains mentioned in the specialized literature. The university, thus, does not seem to be preoccupied about or interested in sustainability.

\subsubsection{Bucharest University of Economic Studies}

Bucharest University of Economic Studies has a strategic plan of 25 pages. Throughout these pages, sustainability is rarely focused upon. The word sustainable appears only twice. The first time, it is mentioned late in the document on page 18, in the context of international affairs, particularly in relation to attracting new students and academic staff and creating multicultural communities. This can be done by achieving sustainable partnerships with foreign universities and European institutions. The second time, the word is again used in relation to partnerships, this time referring to the business and institutional environment. The context now is infrastructure and the ways the university can consolidate it in order to serve its research, education and social services. From another perspective, the first instance refers to the domain of internationalization (III1), while the second one (III2) refers to the domains of technological capacity building and quality teaching, respectively. Bucharest University of Economic Studies seems, then, to associate sustainability with partnerships in fields related to international affairs and infrastructure.

\subsection{4. "Carol Davila" University of Medicine and Pharmacy Bucharest}

The strategic development plan of "Carol Davila" University of Medicine and Pharmacy Bucharest covers 30 pages. The concept of sustainability appears only three times, as sustainable and durable development. Durable development is one of the results expected by the university after applying the detailed strategic plan, alongside excellency in education, research and innovation. It is, thus, one of its main general objectives. The word sustainable is associated with contribution, this becoming necessary for a sustainable development of society and the achievement of the highest standard of health in Romania, the EU and the world. As such, the university becomes an important actor in the achievement of the above-mentioned aims. The adjective sustainable is also related to feasibility and alternatives that can help the university make a change of state regarding study programs. After an analysis of the students' distribution and characteristics and the formulation of desirable institutional targets, feasible and sustainable alternatives can be identified. So, the domains with which the concept of sustainability is associated are community engagement (IV1, IV2) and quality teaching (IV3). Considering the length of the plan and the frequency of the concept analyzed in this paper, "Carol Davila" University of Medicine and Pharmacy Bucharest seems, thus, not to pay much attention to it.

\subsection{5. "Gheorghe Asachi" Technical University of Iași}

"Gheorghe Asachi" Technical University of Iași presents its strategic plan for 2016-2020 throughout 67 pages. Within its strategy, the concept of sustainability appears only twice. Financial sustainability is mentioned first, being a desideratum for the establishment of an efficient and effective management. As for durable development, this is among the objectives and strategies regarding the research and innovation within the university. In other words, the first instance (V1) refers to none of the seven domains, while the second one (V2) refers to research culture and community engagement. Technological, economic and socio-cultural progress is aimed at from the perspective of sustainability, together with that of knowledge, these two being important qualities of a society. 


\subsubsection{Politehnica University of Bucharest}

Politehnica University of Bucharest mentions the concept of sustainability several times throughout the 64 pages of its strategic development plan. It appears for the first time on page 5 , in the foreword addressed by the rector of the university. Using the inclusive pronoun 'we', the rector includes himself in a team that has always tried to face the technological, economic, social and sustainable development-related challenges of the environment in which it operates. The achievement of these goals is called evolution. The discourse then turns to the past and depicts what the university has achieved during the past 4 years. Among the strategic achievements mentioned, the improvement of the university's infrastructure is pointed out. It is within this framework that sustainable is mentioned, as a new possibility to integrate biodiesel production, as part of the creation of new research centers and laboratories financed by the Operational Program 'Increase of Economic Competitiveness'.

To continue, durable development is brought into discussion when presenting the university's social responsibility. In order to support this idea, quotes from a known author are used. This reference seems to confirm the statement and to give it even more veracity and credibility. Sustainability, a synonym of sustainable development (durable development), is further related to social responsibility, which is one of the objectives and actions imposed by the current context onto Politehnica University of Bucharest. It can be achieved by promoting certain values, such as justice, ethics, freedom and sustainability. The concept, thus, gains a social value that is highlighted as such by its strategic plan.

Moving to the future, durable development remains a current context. The university wishes to create future grants for students, so that they get more involved in research activities that innovate and adapt technology, supporting, in the end, sustainability. Towards the end of the document, sustainability is associated with the financial aspect. In the medium and long term, it is desired that the economic-financial management continues to take into consideration the ensuring of the university's financial sustainability, in all the elements of its functioning.

Looking at the concept of sustainability from the perspective of the domains with which it is explicitly associated in the university's strategic plan, it can be noticed that great emphasis is placed on research culture (VII1, VII2, VII5), community engagement (VII1, VII3, VII4), natural environment (VII1), and technological capacity building (VII2). The last instance (VII6) makes reference to none of the seven domains in which a sustainable university must excel.

All in all, Politehnica University of Bucharest highlights the concept of sustainability, linking it to the past, present and future, as an issue related to challenges, social value, social responsibility and finances.

\subsubsection{Politehnica University Timişoara}

The strategic plan for 2016-2020 of Politehnica University Timişoara covers 38 pages. The concept of sustainability is extensively used. Durable development is one of the central topics of the plan, representing one of the main strategic axes, together with higher education, research and human resources. Linking the concept to infrastructure may give a technical or engineering notion to durable development. Then, the document explains in detail the strategic axes and the directions that contribute to the accomplishment of the mission. Further on, sustainability is related to the development strategy for human resources, which aims to be sustainable in the long term in order to obtain an increase in human capital. The university considers this to be its main catalyst. Once again, durable development is reiterated to be among the university's strategic objectives, somewhere in the middle of its ranking.

Sustainability as a concept is presented as one of the support activities necessary for durable development. Politehnica University Timişoara wants to be part of sustainable development partnerships, being preoccupied with society and collaboration with others. It becomes an objective, not only at an institutional level, but also at a regional one. Different entities gather their forces to guarantee durable development. The concept is further transferred to the university's own development. Durable institutional development is a desideratum for the future of the university, having as a target 2025, considered a crucial year for education. University governance focuses on an efficient leadership able to 
ensure durable development and to observe the university's specificity. Finally, durable development ends up being part of the social and public policies, unifying the academic environment with the extra-university one.

Taking the entire document into consideration, the domains referred to by the explicit use of the concept of sustainability are quality teaching (VIII4), technological capacity building (VIII4) and community engagement (VIII5, VIII6, VIII7, VIII9). There are however several instances (VIII1, VIII2, VIII3, VIII8) that do not indicate any of the seven domains mentioned in the research methodology.

To summarize, Politehnica University Timişoara places much importance on sustainability, and especially on durable development, in its strategic plan. Frequently used, the concept moves from specific to general, from the university to partnerships between universities and economic agents and, then, to the extra-university environment. In this way, the university occupies the appropriate and natural place on the public scene, that of a message carrier, always innovating and thinking about a sustainable future.

\subsubsection{Technical University of Cluj-Napoca}

The Technical University of Cluj-Napoca presents its strategic plan in 30 pages. Within these pages, the concept of sustainability does not appear frequently. It is used from the beginning of the document, as the university introduces the idea of durable development. The university situates itself among many other universities in the country that are facing opportunities for durable development. It considers durable development to be, at the same time, a challenge to and a necessity for current society. Sustainability as such appears just once and is presented in relation to financial issues. The university recognizes the importance of financial sustainability and sees the chronic underfunding of higher education as a general threat. In the future, this may pose difficulties to the provision of education. Towards the end of the document, the concept of durable development is used again, moving from particular to general, from university to society. The Technical University of Cluj-Napoca supports the accessing of structural funds for strategic and institutional projects in order to obtain a durable urban development.

To put it differently, the concept of sustainability is associated with the domains of community engagement (IX1, IX3), quality teaching (IX1) and research culture (IX1). The second instance (IX2) refers to none of the seven domains.

Taking all this into consideration, the concept of sustainability, seen as a challenge and an opportunity, is related to issues such as quality teaching and community engagement, and is not given a huge prominence in the strategic plan of the university in question.

\subsubsection{University of Agricultural Sciences and Veterinary Medicine Cluj-Napoca}

The University of Agricultural Sciences and Veterinary Medicine Cluj-Napoca presents its strategic plan for 2016-2020 throughout seven pages. The concept of sustainability appears twice in the form of the adjective sustainable. The first time it appears, it is at the beginning of the document, modifying the noun 'projects'. It is mentioned as one of the university's strategic objectives and specific action directions. Being accompanied by 'priority', support for sustainable projects also becomes a priority for the university. The second time, it is used in the last point of the document, dedicated to financial support for strategic objectives. Here, it is related to financial issues and education and refers to funds obtained from the tuition fees paid by students. The focus is on the financial contrast between fee-based education in foreign languages and that in Romanian, indicating the necessity of a reassessment. As for the domains the concept is associated with, it stands out that none of the seven domains are considered in this strategic plan (X1, X2). The University of Agricultural Sciences and Veterinary Medicine Cluj-Napoca considers the concept of sustainability twice throughout a short strategic plan, which is quite frequent considering the length of the document. However, it is not related to development, environment or society. 


\subsubsection{University of Bucharest}

The plan presenting the strategic development of the University of Bucharest for the period 2016-2020 has 11 pages. From the very beginning, the five fundamental principles promoted by this university regarding research and academic training are clearly and briefly presented. Alongside non-discriminatory access and critical thinking, scientific research and academic training are also named within the current context, i.e., from the perspective of principles governing durable development and sustainability. The association of the two concepts seems to strengthen the idea itself. The above-mentioned principles lead to the definition of the university's values, which also point out several action directions. Ensuring the sustainability of the university is one of them. The discourse goes from general, i.e., the sustainability of the current context and contemporaneous society, to specific, more exactly, the sustainability of the institution, and then again to general, more particularly to Romania's development. The latter is an objective for which the university wants to act in order to adopt certain adequate public policies. The University of Bucharest's statement is that education is a long-term investment that has a crucial role for the sustainability of Romania's development. From the point of view of the tackled domains, quality teaching (XI1, XI2), research culture (XI1, XI2) and community engagement (XI4) are emphasized. However, there is one instance (XI3) in which the concept does not relate to any of the seven domains. Considering all this, the University of Bucharest focuses on the concept of sustainability, linking it to research, education, the institution and Romania itself.

\subsubsection{University of Medicine and Pharmacy "Grigore T. Popa” Iași}

The University of Medicine and Pharmacy "Grigore T. Popa" Iași presents its strategic development plan in 84 pages. Only on page 57 does the concept of sustainability appear for the first time. A lack of sustainable development is considered a threat to the university. Sustainability is also related to proposals and feasibility. It seems the concept is related to a social value, which becomes a necessity for the university. The entire strategy of the university aims to contribute to the durable and sustainable development of the institution. The use of both adjectives emphasizes the idea of development. Finally, sustainability is directly related to the institution. By sustainable development, the institution itself becomes sustainable. In relation to the future, the words chosen sound like a promise by the university for the near future. A new aspect introduced in the last example is the financial one, thus also linking the institution to financial sustainability. In terms of the domains that should be developed in order to build a sustainable university, the explicit uses of the concept (XII1, XII2, XII3, XII4, XII5) make reference to none of them. All in all, the concept of sustainability is rarely present in the document, considering its length. When it is present, it is related to strategy, development, financial issues and institution. This indicates that the idea of sustainability is not a top priority for the University of Medicine and Pharmacy "Grigore T. Popa" Iași. It is, however, among its necessary objectives.

\section{Discussion}

The present study has focused on the twelve Romanian universities classified as advanced researchand teaching-oriented universities by the Romanian Ministry of Education in 2011, specifically in terms of the frequency and manner in which they explicitly use the concept of sustainability in their strategic plans for the period 2016-2020 (2014-2020 in the case of Bucharest University of Economic Studies). Attention has been paid quantitatively and qualitatively to the words sustainability and sustainable, and the phrases sustainable development and durable development within the Appraisal framework and the domains they relate to.

The quantitative analysis revealed the frequency of occurrence of the targeted words in relation to their sum total, indicating that they appear in large number in the plan written by Politehnica University Timişoara (21\%), followed closely by Alexandru Ioan Cuza University of Iaşi (14\%), Politehnica University of Bucharest (14\%) and the University of Medicine and Pharmacy "Grigore T. 
Popa" Iași (12\%); they appeared in small number in the plan belonging to Babeș-Bolyai University (2\%) and not at all in the plan of "Iuliu Haţieganu" University of Medicine and Pharmacy Cluj-Napoca. It seems then that sustainability is not a top priority for most of the universities considered. The analysis also showed that there are some preferences among the words, sustainability being frequently used, at $33 \%$, particularly by Alexandru Ioan Cuza University of Iaşi and the University of Bucharest, as well as durable development, at 33\%, especially by Politehnica University Timişoara, followed by sustainable, which appears just once in $25 \%$ of the strategic plans, and finally sustainable development, which is very rarely or not at all present in the documents analyzed, as indicated by its low percentage, at $9 \%$.

The qualitative approach focused firstly on the evaluation of the strategic plans and the values they assign to the concept of sustainability within the Appraisal framework, indicating certain patterns in the association of concepts. Usually, sustainability was encountered in relation to financial issues (Alexandru Ioan Cuza University of Iaşi, Babeș-Bolyai University, "Gheorghe Asachi" Technical University of Iași, Politehnica University of Bucharest, Technical University of Cluj-Napoca, University of Agricultural Sciences and Veterinary Medicine Cluj-Napoca, University of Medicine and Pharmacy "Grigore T. Popa" Iași), education (Alexandru Ioan Cuza University of Iaşi, "Carol Davila" University of Medicine and Pharmacy Bucharest, Politehnica University of Bucharest, Technical University of Cluj-Napoca, University of Agricultural Sciences and Veterinary Medicine Cluj-Napoca, University of Bucharest) and society ("Carol Davila" University of Medicine and Pharmacy Bucharest, "Gheorghe Asachi" Technical University of Iași, Politehnica University Timişoara, Technical University of Cluj-Napoca, University of Bucharest). Certain universities went into further detail and presented the concept in terms of social value (Politehnica University of Bucharest, University of Medicine and Pharmacy “Grigore T. Popa" Iași), social and public policy (Politehnica University Timişoara) and social responsibility (Politehnica University of Bucharest).

Some universities linked sustainability to research, such as Alexandru Ioan Cuza University of Iaşi, "Gheorghe Asachi" Technical University of Iași and the University of Bucharest; to innovation and progress, particularly "Gheorghe Asachi" Technical University of Iași and Politehnica University of Bucharest; to the future, e.g., Politehnica University of Bucharest and the University of Medicine and Pharmacy "Grigore T. Popa" Iași; to infrastructure, namely, Bucharest University of Economic Studies, Politehnica University of Bucharest, Politehnica University Timişoara; to international affairs, in the case of the Technical University of Cluj-Napoca; and to human resources, e.g., Alexandru Ioan Cuza University of Iaşi and Politehnica University Timişoara.

For others, sustainability turned out to be a primary general objective ("Carol Davila" University of Medicine and Pharmacy Bucharest, Politehnica University Timişoara, University of Agricultural Sciences and Veterinary Medicine Cluj-Napoca), an institutional value (University of Bucharest, University of Medicine and Pharmacy "Grigore T. Popa" Iași) or a challenge (Politehnica University of Bucharest, Technical University of Cluj-Napoca). In some cases, the concept was introduced by the rectors of the university themselves, e.g., Alexandru Ioan Cuza University of Iaşi and Politehnica University of Bucharest.

Rarely, the concept of sustainability was considered as a necessary objective (University of Medicine and Pharmacy "Grigore T. Popa" Iași), a lack of which can be a threat to the university (University of Medicine and Pharmacy "Grigore T. Popa" Iași); as a regional objective and partnership (Bucharest University of Economic Studies, Politehnica University Timişoara); as linked to Romania's development (University of Bucharest); or as contributing to national, European and international health, in the case of "Carol Davila" University of Medicine and Pharmacy Bucharest.

As for the association between the concept of sustainability and the domains in which a university should excel—quality teaching, research culture, technological capacity building, accessibility to university education, community engagement, internationalization and natural environment-and in which sustainable measures should be implemented, one can notice that there is a higher tendency to link the concept to certain domains than others, or even to link it to none of the domains at all. Quality teaching is referred to in the strategic plans of the following universities: Alexandru Ioan 
Cuza University of Iaşi (I2, I4, I6), Bucharest University of Economic Studies (III2), "Carol Davila" University of Medicine and Pharmacy Bucharest (IV3), Politehnica University Timişoara (VIII4), the Technical University of Cluj-Napoca (IX1), and the University of Bucharest (XI1, XI2). Research culture is associated with sustainability in the cases of Alexandru Ioan Cuza University of Iaşi (I2, I5, I6), "Gheorghe Asachi" Technical University of Iași (V2), Politehnica University of Bucharest (VII1, VII2, VII5), the Technical University of Cluj-Napoca (IX1) and the University of Bucharest (XI1, XI2). Technological capacity building is related to the concept of sustainability in the strategic plans of Bucharest University of Economic Studies (III2), Politehnica University of Bucharest (VII2) and Politehnica University Timişoara (VIII4). An association of sustainability with the domain of community engagement is encountered in the cases of Alexandru Ioan Cuza University of Iaşi (I5), "Carol Davila" University of Medicine and Pharmacy Bucharest (IV1, IV2), "Gheorghe Asachi" Technical University of Iași (V2), Politehnica University of Bucharest (VII1, VII3, VII4), Politehnica University Timişoara (VIII5, VIII6, VIII7, VIII9), the Technical University of Cluj-Napoca (IX1, IX3) and the University of Bucharest (XI4). Internationalization and natural environment appear related to the concept of sustainability only once each time, namely, in the strategic plan of Bucharest University of Economic Studies (III1), and that of Politehnica University of Bucharest (VII1), respectively.

Interestingly, accessibility to university education is linked to the concept in none of the strategic plans. Moreover, the concept of sustainability is not associated with any of the domains aforementioned in several situations: Babeș-Bolyai University (II1), “Gheorghe Asachi” Technical University of Iași (V1), Politehnica University of Bucharest (VII6), the Technical University of Cluj-Napoca (IX2), University of Agricultural Sciences and Veterinary Medicine Cluj-Napoca (X1, X2) and the University of Medicine and Pharmacy "Grigore T. Popa" Iași (XII1, XII2, XII3, XII4).

\section{Conclusions}

The present study has presented a short overview of the origin of the concept of sustainability and its importance for contemporary society. Being a relatively new concept, universities as promoters of the newest and most innovative ideas that may positively reshape the face of the world we live in have the major role of raising awareness about this new issue challenging our society. Moreover, they should not only draw citizens' attention to the topic but should also implement sustainable measures at the university level in order to generate a new way of thinking among their students, who are the future decision makers in our society. Taking all this and the literature review into account, the present research has focused on the 2016-2020 strategic plans of top Romanian universities (twelve in number) as the institutions' concern to build sustainable universities should come out of their strategic plans that present their situation, status, objectives, threats and position in the academic, economic and social context. Therefore, the following question was raised by the present study: What is the position taken by the top Romanian universities towards sustainable development and stated in their strategic plans? The two hypotheses underlying the present study (i.e., "H1: The concept of sustainability is used frequently in all the strategic plans analyzed", and "H2: The concept of sustainability appears in the universities' strategic plans in relation to the domains in which sustainable universities must perform") were considered to set both the primary objective (i.e., highlighting the stance taken by the top Romanian universities towards their sustainable development) and the three secondary objectives (i.e., identification of the words sustainability and sustainable, and of the phrases sustainable development and durable development in the universities' strategic plans for 2016-2020, quantification of their frequency, and analysis of their linguistic context).

The completed quantitative analysis revealed the frequency of occurrence of the above-mentioned words and phrases. Thus, two important results are highlighted. The first result refers to the general use of the concept of sustainability in the strategic plans considered, namely, $21 \%$ of all instances analyzed was the highest frequency encountered, while $0 \%$ was the lowest. The second result emphasizes the preferences that Romanian users have in terms of the words or phrases. In this regard, sustainability and durable development are most frequently used (33\%), followed by sustainable $(25 \%)$ and sustainable 
development (9\%). The findings of the quantitative analysis show that the first hypothesis is invalid since the highest frequency is not even a quarter of all instances analyzed, and one university does not use the concept at all. Due to the importance given to the topic across the world, it would have been expected that top Romanian universities pay more attention to furthering the concept of sustainability and thus educating the public.

Taking into account the two perspectives from which the qualitative analysis was performed, it was noted that improving access to education is not considered in any of the strategic plans, and that involvement in the community is most often seen as a sustainable contribution of the university to the development of society. Furthermore, the concept of sustainability is often associated with other domains (e.g., finance, economy and health) rather than the ones in which sustainable universities must perform, being an institutional objective that is perceived as a challenge, but also as a threat for the future if not given proper attention. The qualitative analysis thus partially validates the second hypothesis since the concept is associated with almost all the domains in which a sustainable university must perform, being linked to other domains as well.

The present research has answered the research question posed and has therefore shown that, in most cases, building a sustainable university is not a major concern of the university management. This is also emphasized by the fact that the concept is not explicitly mentioned and associated with all the seven domains in which sustainable measures should be implemented. A preference for the word sustainability and for the phrase durable development was also revealed in the 2016-2020 strategic plans of the top Romanian universities. To conclude, although the study has focused on the most important Romanian universities, it has highlighted that they are just in the infant phase, with further and firmer measures being needed in order to become promoters of sustainable development.

Taking this study as a starting point for further research, comparative analyses may be carried out in order to identify the directions in which the top Romanian universities may be heading in the future in relation to sustainable development. Thus, for example, a more complex analysis may be performed comparatively, either diachronically or synchronically, on various sets of data, considering the 2020-2024 strategic plans. This may lead to the development and testing of a methodological tool.

Author Contributions: Conceptualization, V.G. and S.Ș.; methodology, V.G., S.Ș. and C.E.S.; validation, S.Ș., C.E.S. and V.G.; formal analysis, S.S., C.E.S. and V.G.; investigation, S.S., C.E.S. and V.G.; resources, S.S., V.G. and C.E.S.; writing-original draft preparation, S.S., C.E.S. and V.G.; writing-review and editing, S.Ș. and C.E.S.; supervision, S.S., C.E.S. and V.G. All authors have read and agreed to the published version of the manuscript.

Funding: This research received no external funding.

Conflicts of Interest: The authors declare no conflict of interest.

\section{Appendix A (Source Language of the Instances Translated into English in Tables 2-12)}

(I1) Stabilirea unui dialog institutional eficient cu autoritatile de management si organismele de implementare, atat in faza de consultari si precontractare, cat si in faza de implementare si sustenabilitate

(I2) Componenta administrativa actioneaza ca un element suport pentru indeplinirea functiilor de educatie si cercetare, fiind totodata una dintre componentele de baza pentru sustenabilitatea activitatii

(I3) Obiectivul specific este asigurarea unui management sustenabil, prin functionarea optima a institutiei si dezvoltarea de noi investitii

(I4) Dezvoltarea acestui tip de activitate poate fi sustenabila si nu aduce costuri suplimentare, putandu-se concretiza intr-o sursa de venituri pentru Universitate

(I5) Valorificarea rezultatelor cercetarii in mediul socio-economic contribuie in mod decisiv la sustenabilitatea activitatii, precum si la asigurarea finantarii necesare

(I6) asigurarea sustenabilitatii calitatii procesului educational si de cercetare-propun un proces de selectarea in corpul academic, in calitate de cadre didactice titulare sau asociate, a specialistilor $\mathrm{cu}$ recunoastere nationala sau internationala precum si promovarea celor mai buni absolventi ai universitatii si a doctoranzilor in activitati didactice si de cercetare stiintifica 
(II1) Creșterea veniturilor UBB și asigurarea sustenabilității financiare a tuturor structurilor din cadrul universității

(III1) Realizarea unor noi parteneriate viabile și sustenabile cu universități din străinătate și instituții europene

(III2) Încheierea unor parteneriate sustenabile pe termen mediu și lung cu mediul de afaceri și cu instituții specializate ale statului din țară și din străinătate

(IV1) Contribuţie sustenabilă a universităţii la dezvoltarea durabilă şi la atingerea celui mai înalt standard de sănătate în România, în UE şi în lume.

(IV2) Contribuţie sustenabilă a universităţii la dezvoltarea durabilă şi la atingerea celui mai înalt standard de sănătate în România, în UE şi în lume.

(IV3) Identificarea de alternative fezabile şi sustenabile pentru trecerea de la starea actuală la cea dezirabilă

(V1) Dezvoltarea unei discipline financiare a instituției, prin evidențierea clară a fluxurilor de intrare și ieșire pe centre de cost ale universitătii, pentru a se menține sustenabilitatea financiară a acesteia

(V2) desfăşurarea activităţii de cercetare ştiinţifică, dezvoltare, inovare şi transfer tehnologic, valorificarea şi diseminarea rezultatelor acestora, cu rol de componente inseparabile de procesul instructiv-formativ, pentru a contribui la progresul tehnologic, economic şi social-cultural, în sensul dezvoltării durabile şi al evoluţiei către societatea cunoaşterii

(VII1) Am încercat perpetuu să găsim soluții pentru provocările tehnologice, economice, sociale sau de dezvoltare sustenabilă a mediului în care activăm

(VII2) Noi posibilități de integrare sustenabilă a producției de biodiesel

(VII3) Există, de asemenea, şi teza prin care responsabilitatea socială a universităţilor „,contribuie la dezvoltarea durabilă, inclusiv la sănătatea și bunăstarea societății, recunoaște așteptările părților interesate, respectă legea și normele internaționale de conduită și este în conformitate cu normele relevante de transparență și răspundere publică" (Martin, 2013)

(VII4) Promovarea valorilor dreptății, eticii, libertății academice, toleranței, democrației participative, egalității de șanse și sustenabilității

(VII5) O preocupare viitoare o constituie implicarea mai mare a studenţilor în activităţi ş̧i proiecte de cercetare, dorindu-se o stimulare a acestora, cu scopul să descopere şi să creeze cunoaştere, să contribuie la realizarea unor inovaţii şi adaptări tehnologice în domeniile specifice, în contextul dezvoltării durabile

(VII6) Pornind de la aceste realități, managementul economico - financiar va trebui să aibă în vedere în continuare asigurarea sustenabilitătii financiare a universității în toate componentele funcţionării sale, pe termen mediu și lung

(VIII1) Axa V: Infrastructura si dezvoltare durabila

(VIII2) Totodata, ele includ si directile de care depind indeplinirea activitatilor aferente misiunii si anume dimensiunea flnanciara si resursele umane, dependente la randul lor de infrastructura si politicile privind dezvoltarea durabila, informatizarea.

(VIII3) Initiativele in acest domeniu vizeaza punerea in aplicare a unei strategii sustenabile pe termen lung pentru a spori performantele capitalului uman

(VIII4) Obiective si activitati suport privind infrastructura si dezvoltarea durabila

(VIII5) Promovarea conceptului de sustenabilitate la nivelul campusului universitar si la celelalte objective ale UPT prin masuri ce au in vedere

(VIII6) continuarea si intensificarea parteneriatelor cu administratia locala in promovarea de proiecte de interes public si dezvoltare sustenabila

(VIII7) Promovarea structurilor regionale de tip cluster, in principal in domeniul dezvoltaril durabile

(VIII8) Dezvoltarea unei strategii manageriale in urmatorii ani, astfel incat anul 2025 (an crucial apreciat de decidentii din domeniul educatiei) UPT sa prezinte un leadership performant, bazat 
pe combinatia flexibila dintre un management profesional specific unui operator economic aflat intr-un sistem concurential agresiv (care sa poata evalua situatia prezenta, sa elaboreze strategii si planuri de actiune care sa poata fi implementate, monitorizate pentru a-si asigura dezvoltarea institutionala durabila)

(VIII9) Cresterea responsabilitatii publice si sociale prin intensificarea dialogului activ cu mediul extrauniversitar, prin implicarea membrilor comunitatii universitare la elaborarea si implementarea unor politici publice, sociale (ex. pentru protejarea mediului inconjurator, sanse si accesul egal, dezvoltare durabila) si sa comunice eficient rezultatele sale in acest domeniu

(IX1) În acest context, Universitatea Tehnică din Cluj-Napoca, la fel ca multe alte universităţi din ţară, se află atât în faţa unor provocări majore cât şi în faţa unor oportunităţi reale de dezvoltare durabilă ambele presupunând însă o abordare pragmatică, realistă, concentrată către nevoile reale ale mediului socio-economic regional şi naţional, prin regândirea şi orientarea întregului proces educaţional, de cercetare ştiinţifică şi inovare spre această cerinţă.

(IX2) subfinanţarea cronică a învăţământului superior şi cercetării din România, generând dificultăţi în asigurarea sustenabilităţii financiare în condiţii de performanţă a actului academic

(IX3) Sprijinirea dezvoltării urbane durabile

(X1) Stimularea iniţiativelor personale sau colective care pot atrage resursele financiare necesare dezvoltării instituţionale, inclusiv retribuirii salariale suplimentare adecvate; susţinerea proiectelor prioritare şi care sunt sustenabile

(X1) În timp ce învăţământul cu taxă în limbi străine este perfect sustenabil financiar, taxele aplicate la multe programe în limba română necesita o reevaluare

(XI1) Cercetarea știintifica și pregatirea academica in perspectiva principiilor dezvoltarii durabile și sustenabilitatii

(XI2) Cercetarea știintifica și pregatirea academica in perspectiva principiilor dezvoltarii durabile și sustenabilitatii

(XI3) Asigurarea sustenabilitatii institutionale a Universității din București prin: Diminuarea deficitelor, Consolidarea culturii institutionale, Dezvoltarea investitiilor

(XI4) Recunoașterea rolului educatiei ca investitie strategica pe termen lung, cruciala pentru sustenabilitatea dezvoltarii Romaniei

(XII1) Lipsa unei strategii de dezvoltare coerente și sustenabile

(XII2) Pentru realizarea portofoliului de investiți a fost estimat bugetul de venituri și cheltuieli pentru a analiza sustenabilitatea și fezabilitatea propunerilor

(XII3) Toate aceste domenii sunt importante pentru dezvoltarea durabilă și sustenabilă a UMF-Iași și se regăsesc în planul de implementare a operaționalizării obiectivelor strategice

(XII4) Toate aceste domenii sunt importante pentru dezvoltarea durabilă și sustenabilă a UMF-Iași și se regăsesc în planul de implementare a operaționalizării obiectivelor strategice

(XII5) Va fi o instituţie în permanentă dezvoltare, orientată către spaţiul internaţional şi sustenabilă din punct de vedere financiar, abordând noi oportunităţi pe măsură ce acestea apar, rămânând fermă şi consecventă în direcţiile sale esenţiale

\section{References}

1. Dastbaz, M. Industry 4.0 (i4.0): The Hype, the Reality, and the Challenges Ahead. In Industry 4.0 and Engineering for a Sustainable Future, 1st ed.; Dastbaz, M., Cochrane, P., Eds.; Springer: Cham, Switzerland, 2004; pp. 1-11.

2. Grigg, D. The Industrial Revolution and Land Transformation. In Land Transformation in Agriculture; Wolman, M.G., Fournier, F.G.A., Eds.; John Wiley \& Sons Ltd: Chichester, UK, 1987; pp. 79-109.

3. McLamb, E. The Ecological Impact of the Industrial Revolution. Eco. Available online: https://www.ecology. com/2011/09/18/ecological-impact-industrial-revolution/ (accessed on 24 December 2019).

4. Schwab, K. The Fourth Industrial Revolution, 1st ed.; Business Crown: New York, NY, USA, 2017; pp. 1-9. 
5. Olson, B.; Rejeski, D. The Challenge Ahead. In Environmentalism E the Technologies of Tomorrow: Shaping the Next Industrial Revolution, 1st ed.; Olson, R., Rejeski, D., Eds.; Island Press: Washington, DC, USA, 2004; pp. 160-176.

6. MacIntosh, R. The Background of Ecology: Theory and Concept, 5th ed.; Cambridge University Press: Cambridge, UK, 2000; pp. 1-9.

7. United Nations Educational, Scientific and Cultural Organization. Available online: https://en.unesco.org/ (accessed on 30 December 2019).

8. Idris, S. Preface. In Promoting Global Sustainability and Cooperation; Idris, S., Ed.; IGI Global: Hershey, PA, USA, 1986; pp. xii-xix.

9. UN Environment Document Repository. United Nations Environment Programme (UNEP). Stockholm Declaration of the United Nations Conference on the Human Environment. Available online: https://wedocs. unep.org/bitstream/handle/20.500.11822/29567/ELGP1StockD.pdf?sequence=1\&isAllowed=y (accessed on 2 January 2019).

10. Lukman, R.; Glavic, P. What are the key elements of a sustainable university? Clean Technol. Environ. Policy 2007, 9, 103-114. [CrossRef]

11. Report of the World Commission on Environment and Development: Our Common Future. Available online: https://sustainabledevelopment.un.org/content/documents/5987our-common-future.pdf (accessed on 24 December 2019).

12. Hussain, T.; Eskildsen, J.; Edgeman, R.; Ismail, M.; Shoukry, A.M.; Gani, S. Imperatives of Sustainable University Excellence: A Conceptual Framework. Sustainability 2019, 11, 5242. [CrossRef]

13. Petcu, D.; Gherheș, V.; Suciu, S.; Obrad, C. Corporate Social Responsibility in Higher Education. Case Study: Romanian Higher Education System. Qual. Manag. High. Educ. 2010, 1, 275-278.

14. Todoruţ, A.V.; Tselentis, V. Organizational Changes in Order to Achieve a Sustainable University. Ann. Univ. "C-tin Brâncuşi" Tg. Jiu Seria Lit. Şt. Soc. 2012, 3, 1-12.

15. Lozano, R.; Lukman, R.; Lozano, F.J.; Huisingh, D.; Lambrechts, W. Declarations for sustainability in higher education: Becoming better leaders, through addressing the university system. J. Clean. Prod. 2011, 48, 10-19. [CrossRef]

16. Dlouhá, J.; Henderson, L.; Kapitulcinova, D.; Mader, C. Sustainability-oriented higher education networks: Characteristics and achievements in the context of the UN DESD. J. Clean. Prod. 2018, 172, 4263-4276. [CrossRef]

17. Van Weenen, H. Towards a Vision of a Sustainable University. Int. J. Sustain. High. Educ. 2000, 1, $20-34$. [CrossRef]

18. Beynaghi, A.; Moztarzadeh, F.; Maknoon, R.; Waas, T.; Mozafari, M.; Huge, J.; Leal Filho, W. Towards an orientation of higher education in the post Rio +20 process: How is the game changing? Futures 2014, 63, 49-67. [CrossRef]

19. Velazquez, L.; Munguia, N.; Platt, A.; Taddei, J. Sustainable university: What can be the matter? J. Clean. Prod. 2006, 14, 810-819. [CrossRef]

20. Denes, C.; Radu, S. Managementul Resurselor și Sustenabilitatea = Resource Management and Sustainability; Editura Universității “Lucian Blaga” din Sibiu: Sibiu, Romania, 2011.

21. Nolin, J.; Brorström, B. The University of Borås as a Sustainable University; University of Borås: Borås, Sweden, 2015.

22. Grecu, V.; Ipiña, N. The Sustainable University-A Model for the Sustainable Organization. Manag. Sustain. Dev. 2014, 6, 15-24. [CrossRef]

23. Franco, I.; Saito, O.; Vaughter, P.; Whereat, J.; Kanie, N.; Takemoto, K. Higher education for sustainable development: Actioning the global goals in policy, curriculum and practice. Sustain. Sci. 2019, 14, 1621-1642. [CrossRef]

24. Boks, C.; Diehl, J.C. Integration of sustainability in regular courses: Experiences in industrial design engineering. J. Clean. Prod. 2006, 14, 932-939. [CrossRef]

25. Lozano, R. Incorporation and institutionalization of SD into universities: Breaking through barriers to change. J. Clean. Prod. 2006, 14, 787-796. [CrossRef]

26. Lozano, R. Diffusion of sustainable development in universities' curricula: An empirical example from Cardiff University. J. Clean. Prod. 2010, 18, 637-644. [CrossRef] 
27. Wemmenhove, R.; De Groot, W. Principles for university curriculum greening-An empirical case study from Tanzania. Int. J. Sustain. High. Educ. 2001, 2, 267-283. [CrossRef]

28. Lungu, C.I.; Caraiani, C.; Dascălu, C. Educaţia pentru sustenabilitate-Premisă a competitivităţii economice postcriză. Econ. Teor. Apl. 2013, XX, 49-68.

29. Huisingh, D.; Mebratu, D. "Educating the educators" as a strategy for enhancing education on cleaner production. J. Clean. Prod. 2000, 8, 439-442. [CrossRef]

30. Holdsworth, S.; Wyborn, C.; Bekessy, S.; Thomas, I. Professional development for education for sustainability: How advanced are Australian universities? Int. J. Sustain. High. Educ. 2008, 9, 131-146. [CrossRef]

31. Deval, L.P.; Murray, T.; Bowles, I.A. Campus Sustainability Best Practices: A Resource for Colleges and Universities. Available online: https://www.mass.gov/files/documents/2016/08/ot/lbe-campus-sustainpractices.pdf (accessed on 17 January 2020).

32. Sonetti, G.; Lombardi, P.; Chelleri, L. True Green and Sustainable University Campuses? Toward a Clusters Approach. Sustainability 2016, 8, 83. [CrossRef]

33. Lozano, R. The State of Sustainability Reporting in Universities. Int. J. Sustain. High. Educ. 2011, 12, 67-78. [CrossRef]

34. Weerts, D.J.; Sandmann, L.R. Building a two-way street: Challenges and opportunities for community engagement at research universities. Rev. High. Educ. 2008, 32, 73-106. [CrossRef]

35. Bender, G. Exploring conceptual models for community engagement at higher education institutions in South Africa: Conversation. Perspect. Educ. 2008, 26, 81-95.

36. Le Clus, M. Tracking and measuring engagement: A review of the literature. Australas. J. Univ. Community Engagem. 2012, 7, 21-28.

37. Appe, S.; Barragán, D. Universities, NGOs, and civil society sustainability: Preliminary lessons from Ecuador. Dev. Pract. 2017, 27, 472-486. [CrossRef]

38. Noel, J.; Earwicker, D.P. Documenting community engagement practices and outcomes: Insights from recipients of the 2010 Carnegie community engagement classification. J. High. Educ. Outreach Engagem. 2015, 19, 33-62.

39. Legea Educatiei Nationale, nr. 1/2011. Available online: https://www.edu.ro/sites/default/files/_fi \%C8\%99iere/ Minister/2017/legislatie\%20MEN/Legea\%20nr.\%201_2011_actualizata2018.pdf (accessed on 17 December 2019).

40. Ordinul Ministrului nr. 5.262/5.09.2011 (MONITORUL OFICIAL nr. 637/6.09.2011). Available online: http://legislatie.just.ro/Public/DetaliiDocument/131262 (accessed on 17 December 2019).

41. Sinclair, J. Corpus, Concordance, Collocation; Oxford University Press: Oxford, UK, 1991.

42. Tribble, C.; Jones, G. Concordances in the Classroom; Athelstan: Houston, TX, USA, 1997.

43. Baron, A.; Rayson, P.; Archer, D. Word frequency and keyword statistics in historical corpus linguistics. Angl. Int. J. Eng. St. 2009, 20, 41-67.

44. Popescu, I.-I. Word Frequency Studies; Mouton De Gruyter: Berlin, Germany, 2009.

45. Bybee, J.L.; Hopper, P.J. Frequency and the Emergence of Linguistic Structure; John Benjamins Publishing: Amsterdam, The Netherlands, 2001.

46. Baayen, R.H. Word frequency distributions. In Quantitative Linguistics: An International Handbook [Handbooks of Linguistics and Communication Science; HSK 27]; Köhler, R., Altmann, G., Piotrowski, R.G., Eds.; De Gruyter Mouton: Berlin, Germany, 2005; pp. 396-409.

47. White, P.R.R. The Appraisal Website 2015. Available online: https://www.grammatics.com/appraisal/index. html (accessed on 1 December 2019).

48. Stoian, C.E. Language and Image: Advertising Discourse across Cultures; JatePress: Szeged, Hungary, (under review).

49. Macken-Horarik, M. APPRAISAL and the special instructiveness of narrative. Text 2003, 23, $285-312$. [CrossRef]

50. White, P.R.R. Beyond Modality and Hedging: A Dialogic View of the Language of Intersubjective Stance. Text 2003, 23, 259-284. [CrossRef]

51. "Iuliu Haţieganu” University of Medicine and Pharmacy Cluj-Napoca. Available online: http://www.umfcluj. ro/universitate-ro/informatii-ro/doc-ro/hs-ro-2 (accessed on 15 November 2019).

52. Alexandru Ioan Cuza University of Iaşi. Available online: https://www.uaic.ro/wp-content/uploads/2016/10/ Planul-strategic-30.09.2016.pdf (accessed on 15 November 2019). 
53. Babeș-Bolyai University. Available online: https://www.ubbcluj.ro/ro/despre/prezentare/files/strategii/plan_ strategic_2016_2020.pdf (accessed on 15 November 2019).

54. Bucharest University of Economic Studies. Available online: https://www.ase.ro/2013_files/despre_ase/ legislatie/strategia14-20/Strategia\%20ASE\%202014-2020.pdf (accessed on 15 November 2019).

55. "Carol Davila" University of Medicine and Pharmacy Bucharest. Available online: https://umfcd.ro/wpcontent/uploads/2016/10/Plan_Strategic_UMF_31.12.2013_SPM.doc (accessed on 15 November 2019).

56. "Gheorghe Asachi" Technical University of Iași. Available online: https://www.tuiasi.ro/uploads/files/plan_ strategic_general_2016-2019_final.pdf (accessed on 15 November 2019).

57. Politehnica University of Bucharest. Available online: https://upb.ro/wp-content/uploads/2018/02/Plan_ strategic_MC_2016-2020.pdf (accessed on 15 November 2019).

58. Politehnica University Timişoara. Available online: https://www.upt.ro/img/files/ps/2016-2020/Plan-strategicUPT_2016-2020.pdf (accessed on 15 November 2019).

59. Technical University of Cluj-Napoca. Available online: https://www.utcluj.ro/media/decisions/2016/07/27/ Plan_strategic.pdf (accessed on 15 November 2019).

60. University of Agricultural Sciences and Veterinary Medicine Cluj-Napoca. Available online: https://www. usamvcluj.ro/index.php/programe-si-stategii/plan-strategic-2016-2020 (accessed on 15 November 2019).

61. University of Bucharest. Available online: https://www.unibuc.ro/wp-content/uploads/2018/12/PlanStrategic-2016-2020.pdf (accessed on 15 November 2019).

62. University of Medicine and Pharmacy "Grigore T. Popa" Iași. Available online: https: //www.umfiasi.ro/ro/universitate/programe-si-strategii/Documents/2019-2020/Plan\%20de\%20Dezvoltare\% 20Strategica\%20pentru\%20perioada\%202016-2020.pdf (accessed on 15 November 2019).

(C) 2020 by the authors. Licensee MDPI, Basel, Switzerland. This article is an open access article distributed under the terms and conditions of the Creative Commons Attribution (CC BY) license (http://creativecommons.org/licenses/by/4.0/). 